4565/WRIR--9n-4052

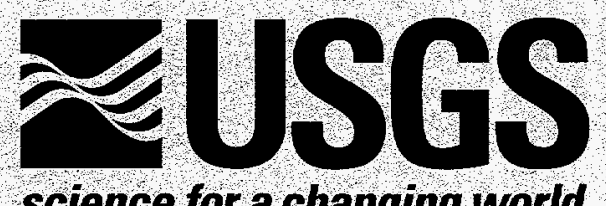

science for a changing world

\title{
AN ESTIMATED POTENTIOMETRIC SURFACE OF THE DEATH VALLEY REGION, NEVADA AND CALIFORNIA, DEVELOPED USING GEOGRAPHIC INFORMATION SYSTEM AND AUTOMATED INTERPOLATION TECHNIQUES
}

U.S. GEOLOGICAL SURVEY

Water-Resources Investigations Report 97-4052

\section{MASTER ,}

DIPTRIRUTION OF THIS DOCUMENT IS UNLMMTED

Prepared in cooperation with the

NEVADA OPERATIONS OFEICE,

U.S. DEPARTMENT OF ENERGY, under

Interagency Agreement DE-AI08-97NV12033 


\section{DISCLAIMER}

Portions of this document may be illegible electronic image products. Images are produced from the best available original document. 


\section{An Estimated Potentiometric Surface of the Death Valley Region, Nevada and California, Developed Using Geographic Information System and Automated Interpolation Techniques}

by Frank A. D'Agnese, Claudia C. Faunt, and A. Keith Turner

\section{U.S. GEOLOGICAL SURVEY}

Water-Resources Investigations Report 97-4052

Prepared in cooperation with the

NEVADA OPERATIONS OFFICE,

U.S. DEPARTMENT OF ENERGY, under

Interagency Agreement DE-Al08-97NV12033 


\title{
U.S. DEPARTMENT OF THE INTERIOR \\ BRUCE BABBITT, Secretary
}

\author{
U.S. GEOLOGICAL SURVEY
}

Thomas J. Casadevall, Acting Director

The use of firm, trade, and brand names in this report is for identification purposes only and does not constitute endorsement by the U.S. Geological Survey.

For additional information write to:

Chief, Earth Science Investigations Program Yucca Mountain Project Branch U.S. Geological Survey Box 25046, Mail Stop 421 Denver Federal Center Denver, CO 80225-0046
Copies of this report can be purchased from:

U.S. Geological Survey Branch of Information Services Box 25286

Denver, CO 80225-0286 


\section{CONTENTS}

Abstract.

Introduction

Physical Setting

Previous Work

Data Acquisition and Preprocessing

Regional Geographic Information System Data Base Construction

Available Data Sets

Water Levels

Lakes and Ponds

Topographic Altitudes

Regional Springs.

Recharge and Discharge Areas .

Hydrogeology

Construction of a Regional Potentiometric Surface

Limitations in Water-Level Data

Interpolation Concepts

Automated Water-Level Interpolation and Editing

Regional Potentiometric Surface Characteristics

Mounds and Depressions

Troughs

Summary.

Le Hydraulic Gradient

\section{PLATE (in pocket)}

Plate 1. Estimated regional potentiometric surface of the Death Valley region, Nevada and California

\section{FIGURES}

1-7. Maps showing:

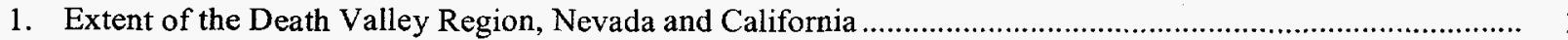

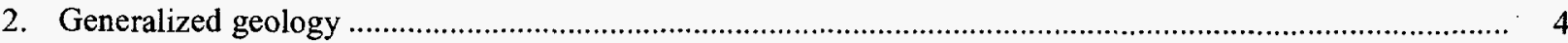

3. Locations of lakes and regional springs.

4. Locations of recharge and discharge areas

5. Locations of water-level data.

6. Locations of breaklines for recharge and discharge areas

7. Locations of selected major structural features...

\section{CONVERSION FACTORS AND VERTICAL DATUM}

\begin{tabular}{rll}
\hline Multiply & By & To obtain \\
\hline kilometer $(\mathrm{km})$ & 0.6214 & mile \\
meter $(\mathrm{m})$ & 3.281 & foot \\
\hline
\end{tabular}

Temperature in degrees Fahrenheit $\left({ }^{\circ} \mathrm{F}\right)$ may be converted to degrees Celsius $\left({ }^{\circ} \mathrm{C}\right)$ as follows:

$$
{ }^{\circ} \mathrm{F}=9 / 5\left({ }^{\circ} \mathrm{C}\right)+32
$$

Sea level: In this report "sea level" refers to the National Geodetic Vertical Datum of 1929 (NGVD of 1929) - a geodetic datum derived from a general adjustment of the first-order level nets of both the United States and Canada, formerly called Sea Level Datum of 1929. 


\title{
An Estimated Potentiometric Surface of the Death Valley Region, Nevada and California, Developed Using Geographic Information System and Automated Interpolation Techniques
}

\author{
By Frank A. D'Agnese, Claudia C. Faunt, and A. Keith Turner
}

\section{ABSTRACT}

An estimated potentiometric surface was constructed for the Death Valley region, Nevada and California, from numerous, disparate data sets. The potentiometric surface was required for conceptualization of the ground-water flow system and for construction of a numerical model.

Because accurate, manual extrapolation of potentiometric levels over large distances is difficult, a geographic-information-system method was developed to incorporate available data and apply hydrogeologic rules during contour construction. Altitudes of lakes, springs, and wetlands, interpreted as areas where the potentiometric surface intercepts the land surface, were combined with water levels from well data. Because interpreted ground-water recharge and discharge areas commonly coincide with groundwater basin boundaries, these areas also were used to constrain a gridding algorithm and to appropriately place local maxima and minima in the potentiometric-surface map.

The resulting initial potentiometric surface was examined to define areas where the algorithm incorrectly extrapolated the potentiometric surface above the land surface. A map of lowpermeability rocks overlaid on the potentiometric surface also indicated areas that required editing based on hydrogeologic reasoning. An interactive editor was used to adjust generated contours to better represent the natural water table conditions, such as large hydraulic gradients and troughs, or "vees". The resulting estimated potentiometric- surface map agreed well with previously constructed maps. Potentiometric-surface characteristics including potentiometric-surface mounds and depressions, surface troughs, and large hydraulic gradients were described.

\section{INTRODUCTION}

Yucca Mountain at the Nevada Test Site in southwestern Nevada is being studied as a potential geologic repository for high-level nuclear-waste (fig. 1). The U.S. Geological Survey (USGS), in cooperation with the U.S. Department of Energy, is evaluating the hydrogeologic characteristics of the site as part of the Yucca Mountain Project. One of the many USGS studies is a detailed characterization of the regional ground-water flow system. This report discusses the construction of a regional potentiometric surface used in these studies.

A large number of parameters are necessary to characterize the regional flow regime. Computerbased methods for storing, analyzing, and visualizing three-dimensional (3D) spatial data are, therefore, used to describe the geologic and hydrologic characteristics of the region. These spatial data are housed in a geographic information system (GIS) so that they can be used for characterizing, or conceptualizing, regional flow and for conducting numerical simulations. This study utilizes information stored within a GIS data base developed by investigators at the USGS as part of the Yucca Mountain Project (Faunt and others, 1993).

This report presents a regional potentiometric surface for the Death Valley region, Nevada and California, and a detailed discussion of the interactive 

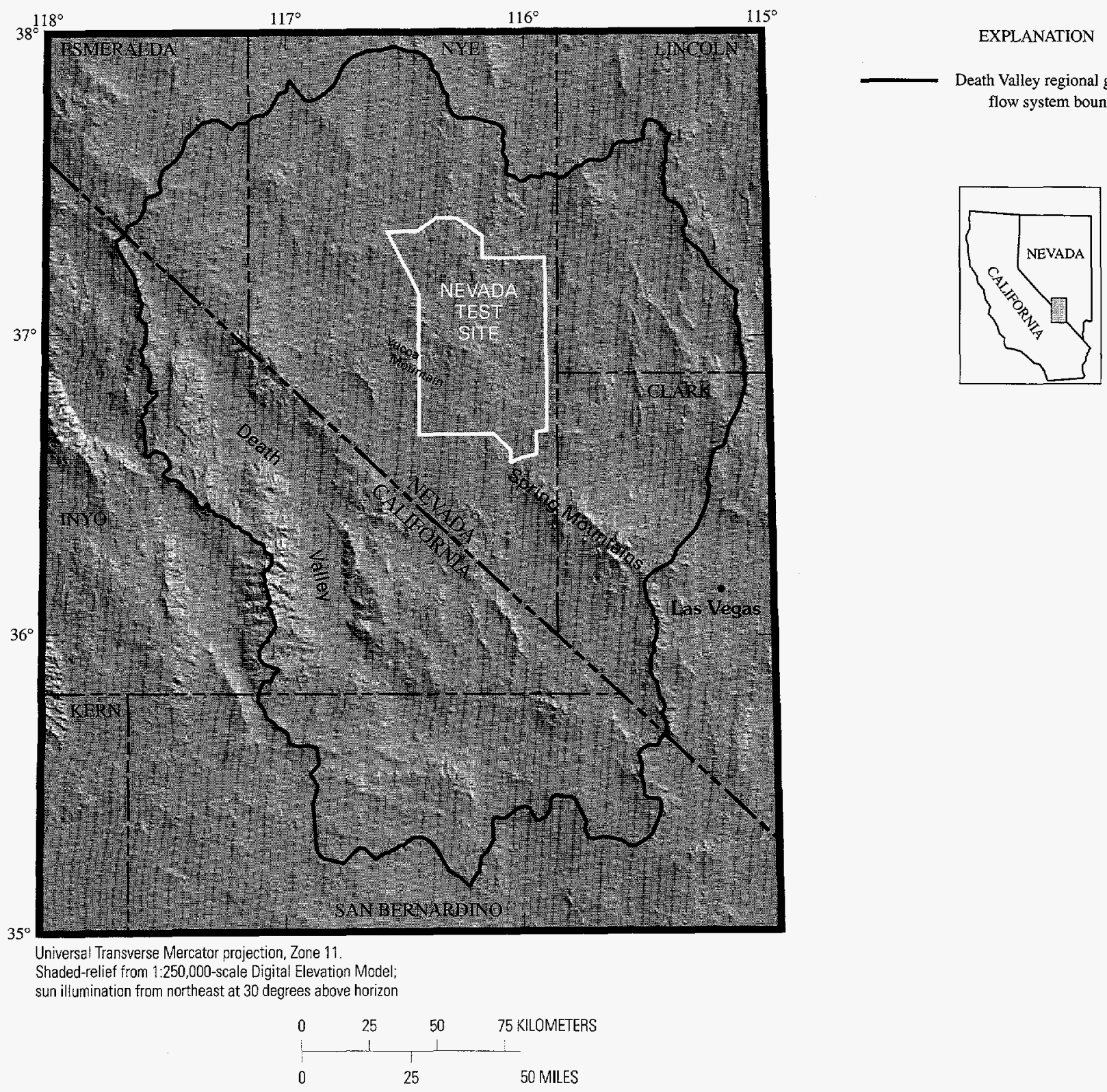

Figure 1. Extent of the Death Valley Region, Nevada and California.

gridding and GIS techniques used to develop it. The discussion includes an explanation of (1) data gathering and preparation methods, (2) digital map construction techniques, and (3) potentiometricsurface characteristics. Existing water-level data, both inside and outside the boundaries of the Death Valley regional ground-water system boundary, were used to construct the potentiometric surface. The potentiometric surface based on these data is assumed to generally represent steady-state ground-water conditions.

\section{PHYSICAL SETTING}

Physiographic, geologic, and hydrologic characteristics of the region exert strong controls on the ground-water flow system. Interactions among these characteristics result in a complex potentiometric surface.

The Death Valley region is situated within the southern Great Basin, a subprovince of the Basin and Range physiographic province (Fenneman, 1931). Late-Cenozoic faulting accounts for much of the 
topographic relief (Grose and Smith, 1989). Altitudes range from 86 meters below sea level at Badwater in Death Valley to 3,600 meters above sea level in the Spring Mountains (fig. 1). The relief between valleys and adjoining mountains locally exceeds 1,000 meters (Bedinger and others, 1989).

The landscapes are visually dominated by isolated mountain ranges rising abruptly from broad, alluvium-filled desert basins. The valley bottoms are occupied by local depositional centers usually marked by playa lakes that act as catchments for surface-water runoff (Grose and Smith, 1989). The Death Valley region is a closed drainage system; no surface water discharges outside of the study area. The largest playa lake in the region, the Death Valley saltpan, is the ultimate discharge area for most of the study area. Most surface-water basins within the region seldom contain perennial water.

The Death Valley region has a long and active geologic history, including intermittent marine and nonmarine sedimentation, large-scale compressive deformation, plutonism, volcanism, and extensional tectonics (Mifflin, 1988). Consequently, diverse rock types, of contrasting ages, often are juxtaposed, and complex deformational structures are common. As a result, subsurface conditions are variable and complex. The potentiometric surface of the region is directly affected by this complex geology. Overall, five dominant rock types are present including basin-fill alluvium of Tertiary and Quaternary age, volcanic rocks of Tertiary age, carbonate rocks of Paleozoic age, and clastic and crystalline rocks of Precambrian and Cambrian age (fig. 2).

The ground-water flow systems of the Death Valley region are extremely complex. Hydraulic compartmentalization of regional ground-water flow paths is thought to occur throughout the study area. This compartmentalization results from the presence of extensive faulting and fracturing occurring in a laterally and vertically extensive carbonate sequence that underdrains the area. As a result, regional groundwater flow patterns often do not coincide with topographic basins.

Ground-water recharge results from infiltration of precipitation and runoff on the high mountain ranges (Bedinger and others, 1989). In several places, these recharge areas support ground-water mounds that may act as physical boundaries to subsurface flow, preventing interbasinal ground-water transfers.
Natural ground-water discharge is by flow to springs and by evapotranspiration in areas where the water table is near the land surface. Human-induced discharge occurs in the form of ground-water pumping for agricultural, commercial, and residential uses (Bedinger and others, 1989).

\section{PREVIOUS WORK}

Numerous potentiometric-surface maps have been developed for basins within the Death Valley region. Most of these maps have been generalized contour maps of shallow unconfined basin-fill aquifers (Malmberg and Eakin, 1962; Walker and Eakin, 1963; Malmberg, 1967; Kilroy, 1991). Other investigations have included more detailed contour maps of shallow and deep regional flow in consolidated rock (Rush, 1970; Thordarson and Robinson, 1971; Blankennagel and Weir, 1973; Winograd and Thordarson, 1975; Robison, 1984; Waddell and others, 1984).

Bedinger and others (1984) and Langer and others (1984) developed maps of ground-water levels and spring discharges for the Nevada and California parts of the Death Valley region, respectively. During these investigations, they noted the difficulty in extrapolating water levels over large distances. Significant conclusions were drawn from these investigations, including the following:

1. Although regional water-level data are spread temporally over several decades, most data for any given basin were gathered during short periods of time;

2. In the unconsolidated basin-fill deposits, the saturated zone is relatively continuous, although perched ground water may occur in isolated areas; and

3. In consolidated bedrock areas with significant topographic relief, particularly in highly fractured rock in which numerous interconnected aquifers exist, the depth to ground water can be predicted with reasonable accuracy between widely spaced water-level data points. Where regional geologic discontinuities, such as fault zones, alter regional flow, such predictions may not be accurate.

A relatively detailed representation of the regional potentiometric surface in the vicinity of Yucca Mountain was developed by Waddell and others (1984). That map incorporated water levels 


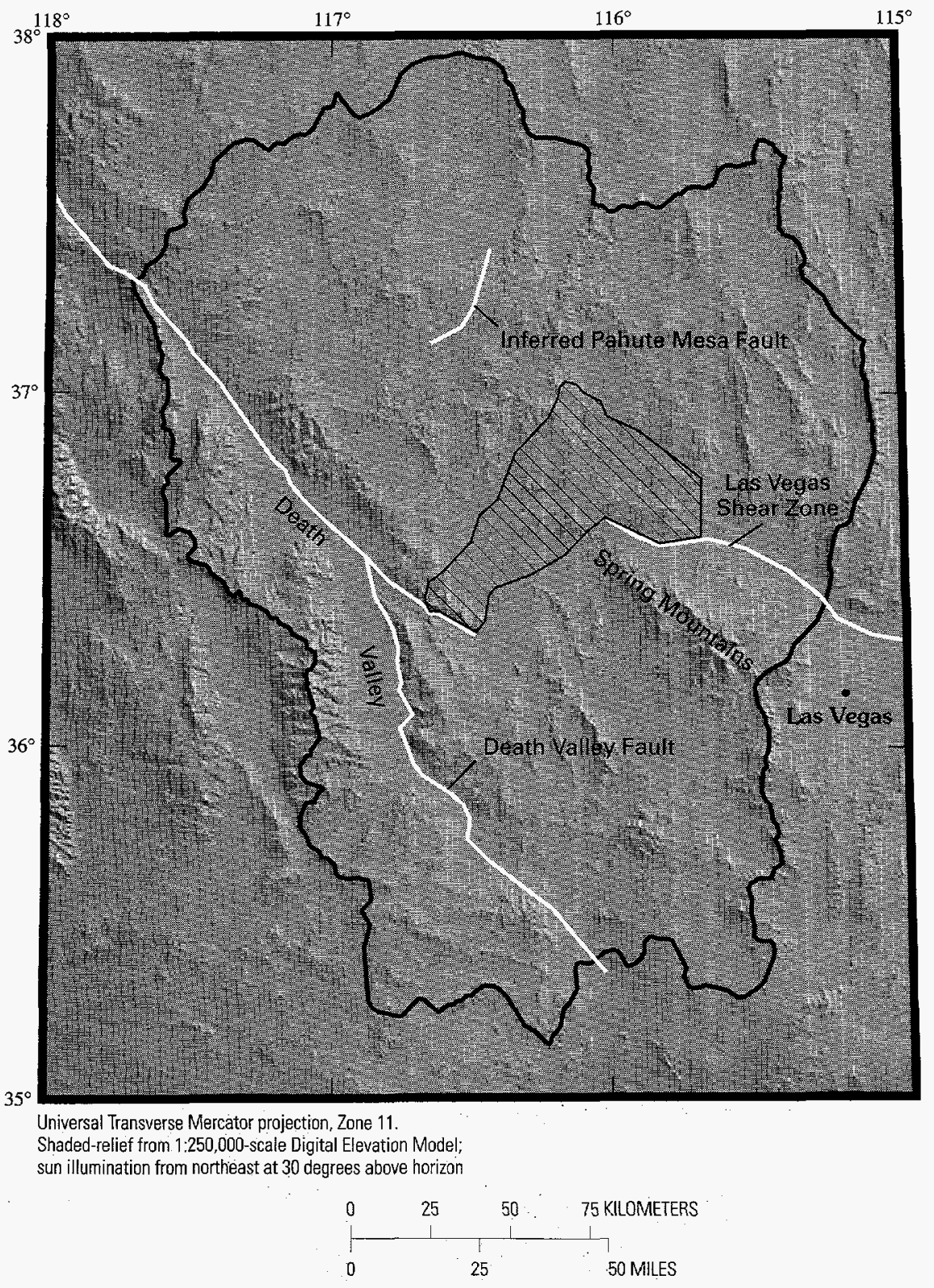

Death Valley regional groundwater flow system boundary

Regional faults affecting regional potentiometric surface

Spotted Range-Mine Mountain structural zone

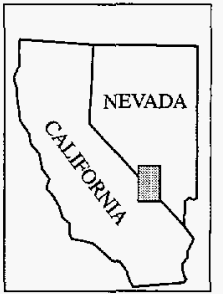

Figure 2. Generalized geology.

from several hydrogeologic units. In some areas, such as Yucca Flat, data were available from wells completed in alluvium, tuff, and carbonate rocks. Potentiometric levels from these distinct units indicate a downward flow toward the carbonate aquifer, but Waddell and others (1984) conclude that potentiometric levels are so similar on a regional scale that contouring separate potentiometric surfaces are not feasible. Ervin and others (1994) and Tucci and Burkhardt (1995) constructed potentiometric-surface maps in the immediate vicinity of Yucca Mountain for 1988 and 1993 conditions, respectively.

\section{DATA ACQUISITION AND PREPROCESSING}

A GIS data base was developed as part of the Yucca Mountain site characterization studies (Faunt and others, 1993). Henceforth referred to as the "GIS 
data base," this collection of digital maps, data files, and remote-sensing images, was developed to directly support regional ground-water characterization.

\section{Regional Geographic Information System Data Base Construction}

Only data appropriate to the regional characterization of the hydrogeologic system of the Death Valley region were gathered and incorporated in the GIS data base. Detailed, large-scale, site-specific data were not included. Publicly available primary data sets were located and acquired for incorporation into the GIS data base. Therefore, no previously unpublished, uncontrolled, or nonquality-assured data were used. For example, water-level data were used only if they had been previously published or quality controlled under an approved Yucca Mountain Project qualityassurance plan and stored in publicly accessible data files. Although no new data were gathered for the study, field checks were conducted to verify existing data. To maintain quality, all data were incorporated into a standardized data base. A detailed discussion of the GIS data base development is described in D’Agnese (1994) and Faunt (1994).

\section{Available Data Sets}

Construction of the regional potentiometricsurface map required data sets describing (1) water levels, (2) boundaries of lakes and ponds,

(3) topographic altitudes, (4) regional spring locations,

(5) the distribution of recharge and discharge areas, and (6) hydrogeology. Brief descriptions of these data sets are given in the following sections.

\section{Water Levels}

All water-well data used in this study originate from the U.S. Geological Survey's National Water Information System (NWIS) data base. These data were gathered over a long period of time (1907 to 1991); however, most data were collected after 1970. These files contain information for regularly monitored wells and springs in an elaborate data structure. The amount of information available for each well in the data base, however, is highly variable.

A detailed query of NWIS was undertaken to retrieve data that would be useful for analyzing water levels in the region. Water-level data for the entire 3-degree by 3-degree area, shown on plate 1, were obtained to provide adequate control of potentiometric-contour locations at the boundary of the Death Valley region. These retrieved data, for 2,141 wells, were converted into a format compatible with the GIS data base, and a well-location map was generated. Because very little information about the screened intervals of these wells was available in the data base, the majority of the water levels were considered to be representations of the water table or composite waterlevel measurements of the regional potentiometric surface.

\section{Lakes and Ponds}

The boundaries of lakes and ponds were obtained from the USGS digital line graph (DLG) cartographic data base (fig. 3). These products contain selected hydrographic information digitized from USGS 1:100,000-scale topographic maps. The data describe all flowing and standing water, springs, and wetlands (U.S. Geological Survey, 1985). Eighteen 1:100,000-scale DLG map products covering the study area were imported into ARC/INFO GIS and joined to develop a digital map describing the surface hydrography characteristics for the entire study area (Turner and others, 1996a).

\section{Topographic Altitudes}

The topographic-altitude data used in this study were obtained from a compilation of Defense Mapping Agency series, 1-degree by 1-degree digital elevation models (DEM's), developed by Turner and others (1996b). DEM's are sampled arrays of landsurface altitudes that are usually, but not always, at regularly spaced intervals (U.S. Geological Survey, 1987). In the study area, the spacing of points on these DEM files is about 70 meters east-west and 90 meters north-south.

Nine DEM's required for this study were imported into ARC/INFO GIS, transformed to the appropriate projection, and joined to develop a rather large, raster terrain model of the region containing 3,601 columns and 3,601 rows. For reasons of data manageability, the terrain model then was resampled by selecting every third cell to develop a DEM that contained an altitude measurement at every 9 arc-seconds of land surface or approximately 

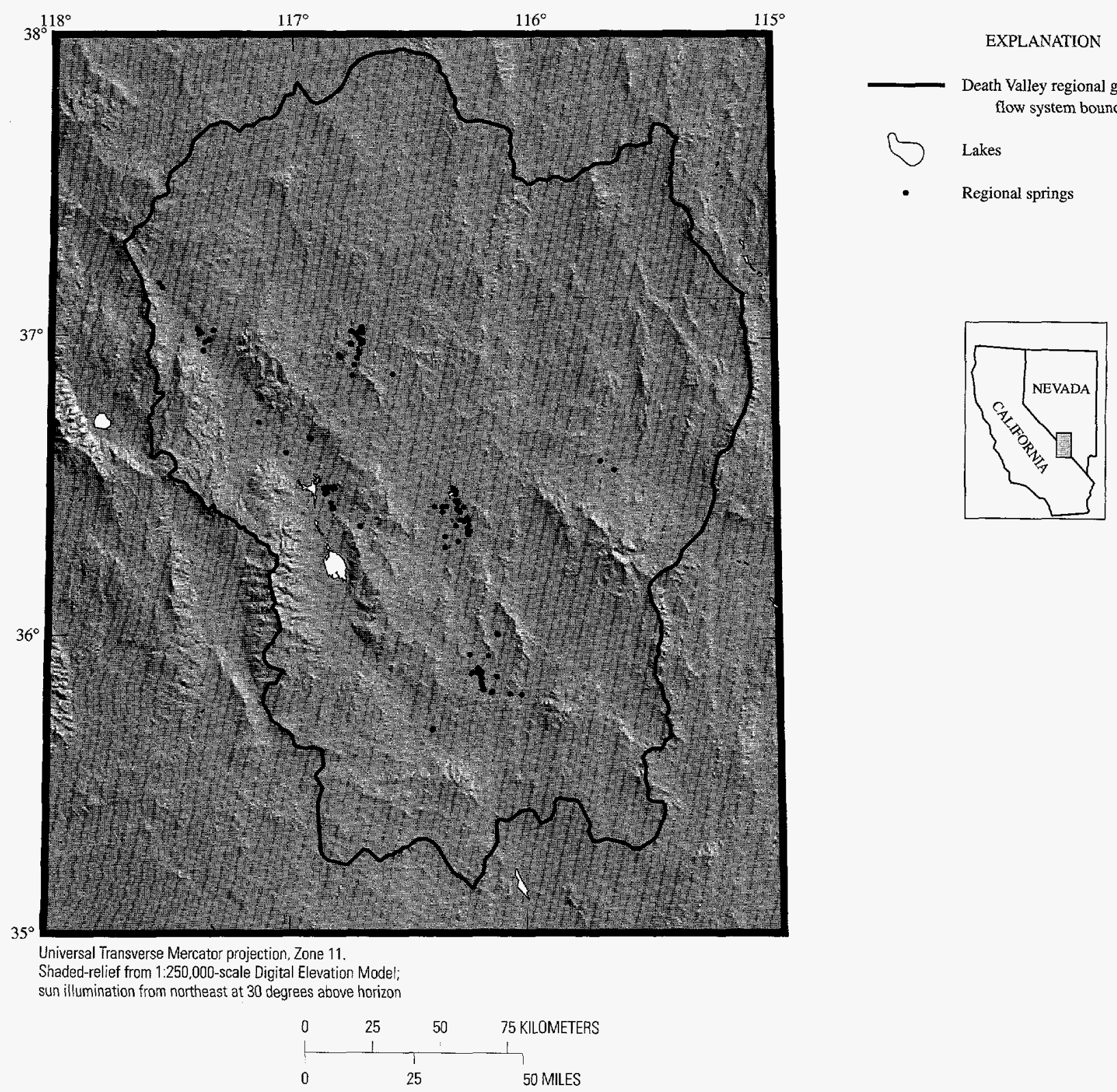

Figure 3. Locations of lakes and regional springs.

210 meters by 270 meters (Turner and others, $1996 \mathrm{~b}$ ). This resampled digital terrain model contained 1,201 columns and 1,201 rows. The expected absolute vertical error for the resampled DEM is believed to be no different than original data set error of 30 meters (Turner and others, 1996b).

\section{Regional Springs}

The location and altitude of all regional spring- discharge points (fig. 3) were used in development of the potentiometric surface. These springs, characterized by steady, large-volume discharges and temperatures ranging from $24^{\circ} \mathrm{C}$ to $35^{\circ} \mathrm{C}$, typically emerge from the regional ground-water flow system by way of the valley fill and the carbonate aquifer at low altitudes along the borders or on the floor of some valleys (Winograd and Thordarson, 1975). The occurrence of these springs are typically a result of

6 An Estimated Potentiometric Surface of the Death Valley Region, Nevada and California, Developed Using Geographic Information System and Automated Interpolation Techniques 
1. an intersection of the water table and the land surface forcing ground water to discharge;

2. intersecting faults or fractures of high permeability that act as conduits directing upward-gradient regional ground water to the surface; or

3. stratigraphic and/or structural juxtaposition of highpermeability materials with low-permeability materials causing an abrupt change in the direction of ground-water flow and forcing flow paths toward the land surface (Pistrang and Kunkel, 1964).

\section{Recharge and Discharge Areas}

The distribution of recharge and discharge areas (fig. 4) also was utilized during construction of the potentiometric-surface map. Image classification methods were applied to multispectral satellite data to produce a vegetation map. The vegetation map was

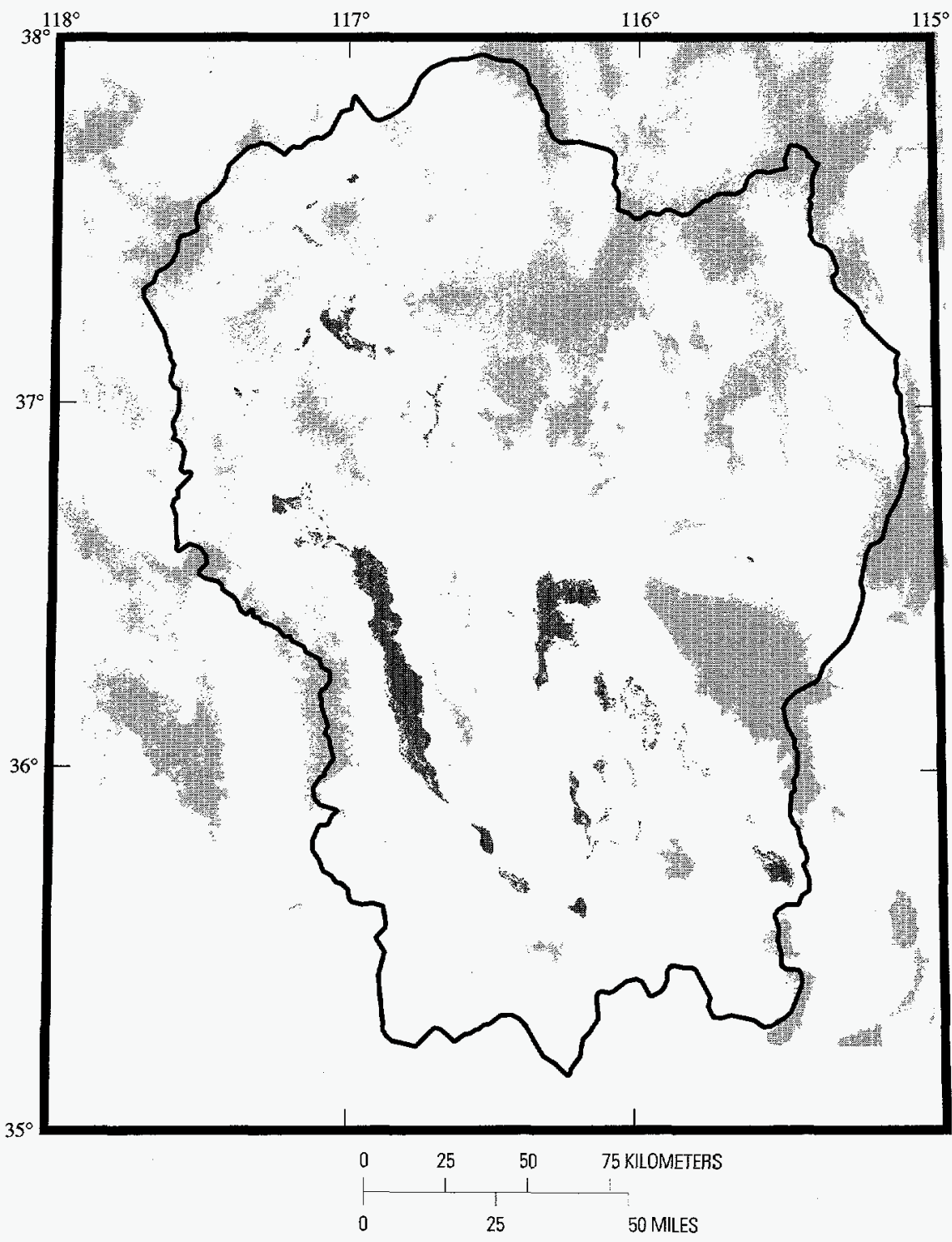

EXPLANATION

Death Valley regional groundwater flow system boundary

Recharge areas

Discharge areas

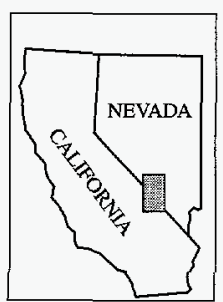

Figure 4. Locations of recharge and discharge areas. 
combined with maps showing regional springs and areas of saline soil to delineate wetland, phreatophyte, and wet-playa discharge areas. Recharge areas were delineated by incorporating thematic maps describing often heterogeneous complex factors affecting infiltration. These factors included (1) topography, (2) slope aspect, (3) parent material, and (4) vegetation, which were incorporated into a recharge map by ranking the factors in order of infiltration potential. The results of both of these substudies were combined into one map describing the areal extent of ground-water recharge and discharge areas (fig. 4).

\section{Hydrogeology}

A regional hydrogeologic map developed by Faunt and others (1997) was used to delineate areas where low-permeability bedrock might influence the configuration of the water table. The regional hydrogeologic map was constructed by combining existing regional geologic maps and report data into a GIS data base, creating a digital regional geologic map, and then combining the diverse geologic map units into fewer hydrogeologic units. For regional potentiometric-surface map construction, the 12 units shown on the hydrogeologic map of Faunt and others (1997) were combined into five generalized geologic units (fig. 2). Basin-fill alluvium and carbonate rocks have relatively high permeability, but clastic and crystalline rocks have relatively low permeability. Permeability of the volcanic-rock units is quite variable and was interpreted as having moderate permeability.

\section{CONSTRUCTION OF A REGIONAL POTENTIOMETRIC SURFACE}

The potentiometric surface is primarily based on regional water-level data, both within and outside the boundaries of the regional flow system. These data were supplemented by additional influencing factors, such as hydrographic data, distribution of lowpermeability geologic units, and the distribution of regional discharge and recharge areas; these additional data served to improve interpolations in areas of sparse well data. Because water-level data in much of the Death Valley region are sparse, the potentiometricsurface shown on plate 1 is termed "estimated".

\section{Limitations in Water-Level Data}

Water-resource extraction and investigation have been mostly concentrated in alluvial basins in this sparsely populated, arid, and mountainous region. As a resuit, clusters of water wells and water-level data are concentrated in these basins. The densest concentration of water-level data in the area occurs near Las Vegas, Nevada, east of the Death Valley regional ground-water flow system (fig. 5). Additional water-level data were obtained within the basin-fill alluvium of Oasis Valley, Amargosa Valley, Pahrump Valley, Sarcobatus Flat, and Yucca Flat (fig. 5). The only areas with extensive water-level data in consolidated bedrock are Yucca Mountain, Pahute Mesa, and Rainier Mesa (fig. 5). In the remainder of the region, water-level data are sparse.

\section{Interpolation Concepts}

The concept of a free-surface water table described by Domenico and Schwartz (1990) was utilized to develop the potentiometric-surface map. They suggest that the regional potentiometric surface in intensely fractured, mountainous regions that have a deeply circulating flow system can be interpreted as a series of semicontinuous, free surfaces connected between basins by large hydraulic gradients. The resulting water-table configuration is, therefore, interpreted as plateau-like surfaces in each subbasin connected by zones of large hydraulic gradients present in mountain blocks of comparatively smaller permeability.

To guide interpolation of water levels in data poor areas, ancillary data were used in accordance with five general criteria:

1. During interpolation, water levels were not permitted to extend above the land surface, defined by the DEM.

2. The altitudes of regional springs, lakes, and ponds were used to define locations where the regional water table occurs at the land surface.

3. Regional discharge areas are regional depressions in the flow system and are located at local minima in the regional potentiometric surface. The potentiometric surface at discharge areas, therefore, was interpolated to form local minima.

4. Regional recharge areas develop recharge mounds (and often, ground-water divides) in the potentio-

8 An Estimated Potentiometric Surface of the Death Valley Region, Nevada and California, Developed Using Geographic Information System and Automated Interpolation Techniques 

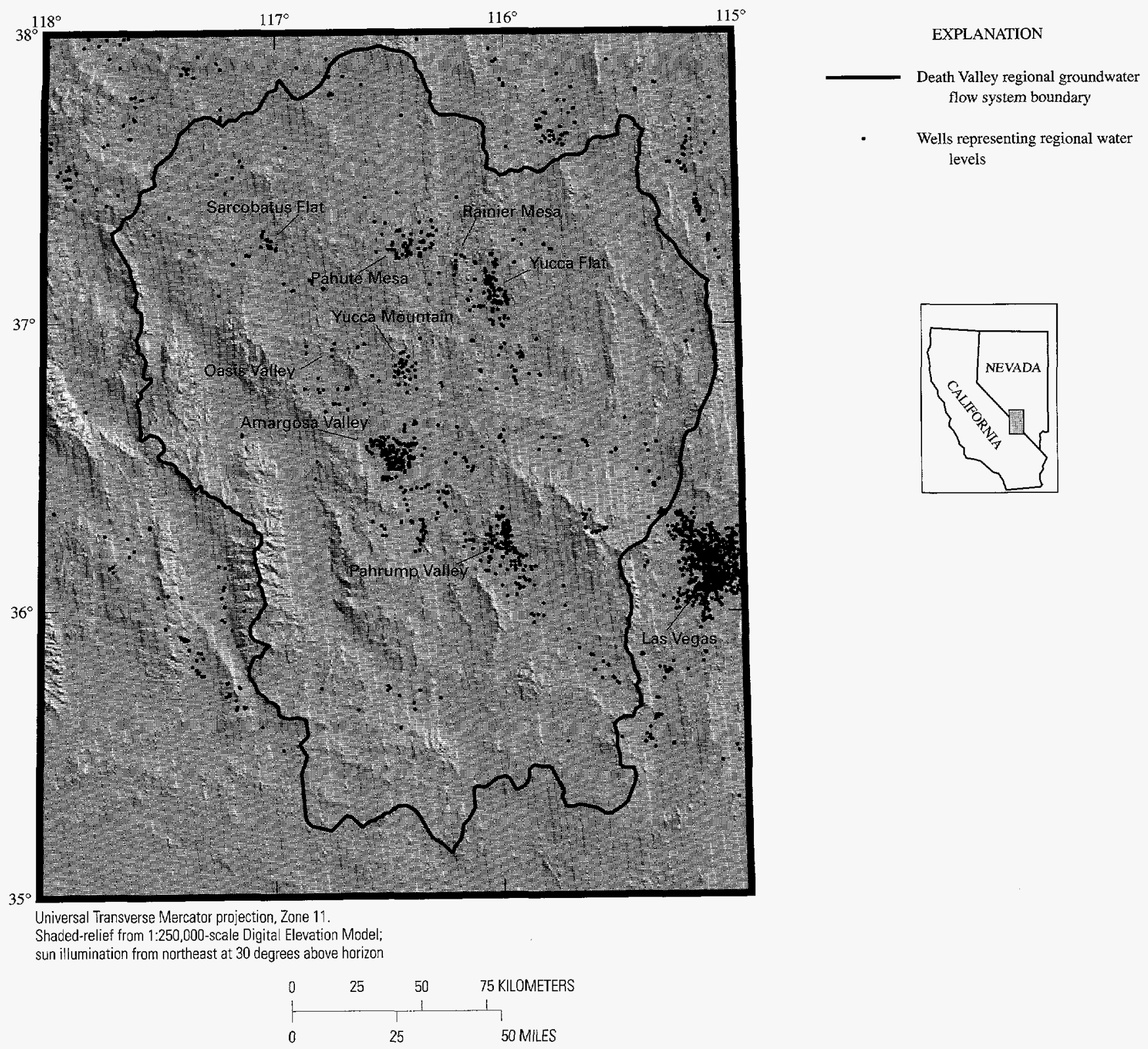

Figure 5. Locations of water-level data.

metric surface. Therefore, the potentiometric surface was interpolated to form local maxima at locations of recharge areas. During subsequent revisions of the interpolated surface, water levels were checked to ensure that they did not extend far above the elevation of localized, cold-temperature springs occurring in these recharge areas.

5. Lower permeability rocks typically affect the potentiometric surface by sharply refracting contours into the units with lower permeability resulting in areas with steep hydraulic gradients. The generalized geologic map (fig. 2) was used to delineate areas interpreted as having surface and subsurface units of lower permeability rock. During interactive interpolation of the potentiometric surface, gradients on the interpreted surface were steepened when necessary to reflect these hydrogeologic barriers. 


\section{Automated Water-Level Interpolation and Editing}

Schlumberger-GeoQuest's CPS-3 gridding and contouring software system was used to incorporate these criteria throughout the map area. CPS-3 applies a convergent gridding algorithm that utilizes a trend surface method to develop a series of successively more refined surfaces that honor all input data throughout a number of converging passes. The resulting surface (1) exactly matches the input data, (2) honors breaklines, where specified, and (3) interpolates surface trends in areas where data are absent.

The gridding and contouring involved several steps. First, water-level altitudes obtained from water wells, regional springs, lakes, and ponds were extracted from the GIS data base and combined to form a digital file of discrete coordinate pairs and water-table altitudes. Next, a map was developed containing the digitized center lines of the recharge and discharge areas (fig. 6). Each center line represents points on the potentiometric surface where the recharge mound or discharge depression result in a change in direction of slope. These areas were interpreted by the gridding algorithm as breaklines, where the surface gradients were interpreted as zero. The data then were interpolated using a convergent gridding algorithm at a grid-cell spacing of $558 \mathrm{~m}$ by $558 \mathrm{~m}$.

The resulting preliminary contour map then was digitally compared to the DEM by developing a residual surface between the two. In areas where the interpolated water table extended above the land surface, the contour map was edited by using CPS-3's "interactive editor". Interactive editor allows the user to manipulate interpolated contour lines by graphically stretching, removing, and redigitizing line strings that define contour lines. The interactive editor then reinterpolates those parts of the grid that have been changed. Areas where contour changes do not mathematically honor the input data points also are highlighted by the interactive editor.

The generalized geologic map (fig. 2) was graphically overlaid on the contour map and additional areas were identified where hydrogeologic conditions may indicate large hydraulic gradients might reasonably be expected. Additional editing was performed to introduce larger gradients in these areas. After a series of these edits and reinterpolations, the resulting potentiometric-surface map was compared with potentiometric-surface maps produced by previous studies (Rush, 1970; Thordarson and Robinson, 1971; Blankennagel and Weir, 1973; Winograd and Thordarson, 1975; Robison, 1984; Waddell and others, 1984). Any major differences in interpretations were identified. These discrepancies were noted and evaluated, and the potentiometric surface was modified to reflect the earlier interpretations in locations where such interpretations appeared to conform to regional conditions and conceptualizations of the regional ground-water flow system.

\section{REGIONAL POTENTIOMETRIC SURFACE CHARACTERISTICS}

Several dominant features of the regional potentiometric-surface map (pl. 1) that are a result of important hydrologic or geologic features include (1) potentiometric-surface mounds and depressions, (2) potentiometric-surface troughs, and (3) large hydraulic gradients. The potentiometric surface may be controlled by topography, lithology, or geologic structure. Examples of all these controls exist in the Death Valley regional ground-water flow system (Winograd and Thordarson, 1975; Carr, 1984; Faunt, 1994).

\section{Mounds and Depressions}

Potentiometric-surface mounds are most commonly associated with ground-water recharge areas, where ground-water infiltration occurs. On the potentiometric-surface map, several recharge mounds are inferred where supporting water-level data do not exist. Recharge conditions and low-permeability rocks occur in these areas, however, which indicates that recharge mounds are likely to exist. Large mounds are associated with areas recharging the regional flow system, but smaller mounds are associated with recharge to subregional or local flow systems. These recharge mounds also may represent semiperched ground-water conditions (Meinzer, 1923, p. 41), which most often occur in recharging ground-water environments. The most prominent mound, and the largest recharge area, is located at the Spring Mountains

(pl. 1, M1). Other smaller recharge mounds are present

10 An Estimated Potentiometric Surface of the Death Valley Region, Nevada and California, Developed Using Geographic Information System and Automated Interpolation Techniques 


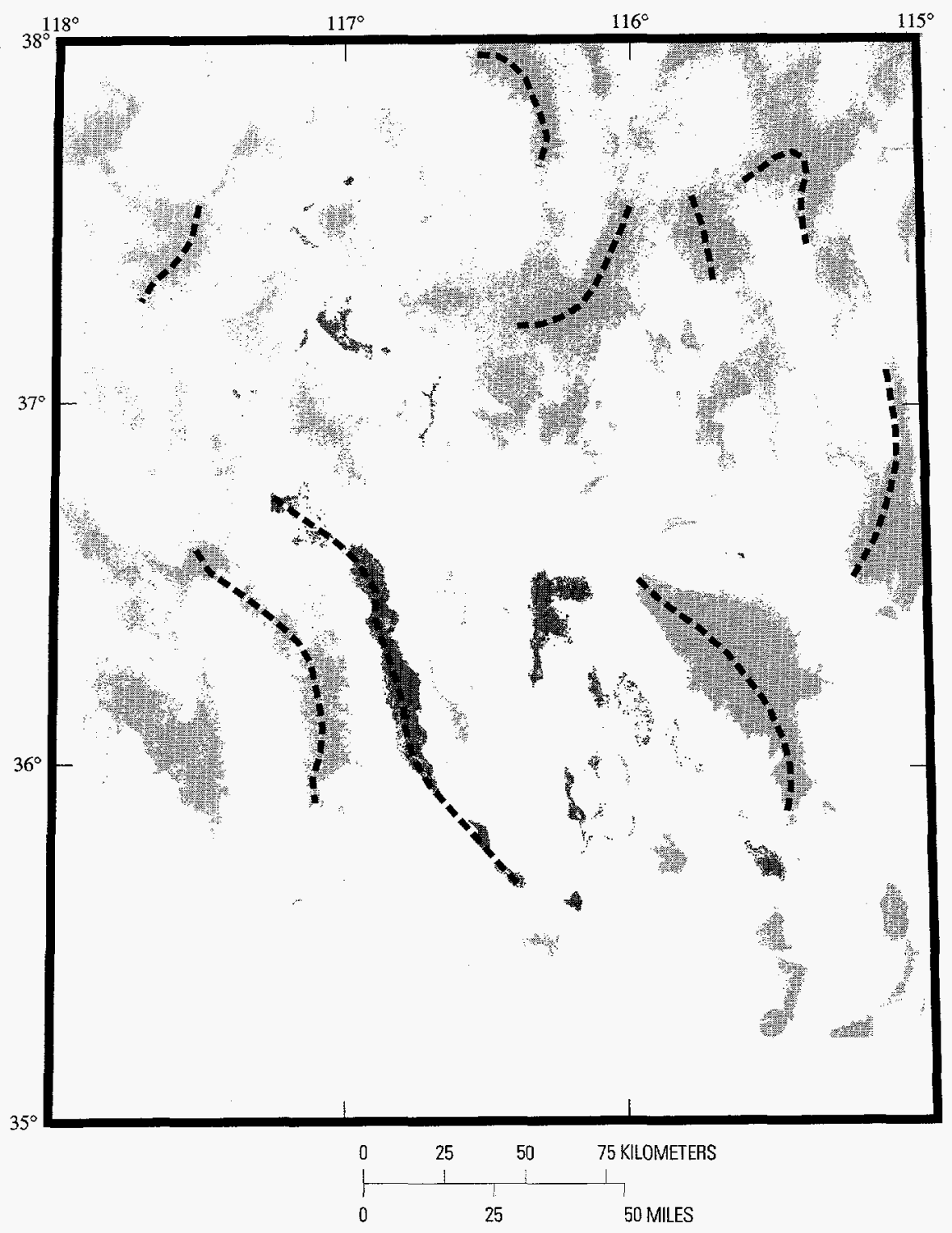

EXPLANATION

Recharge areas

Discharge areas

Breaklines that were used to control relative maxima and minima

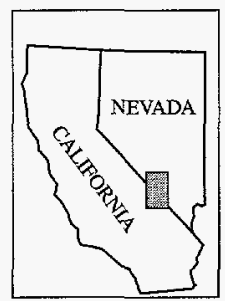

Figure 6. Locations of breaklines for recharge and discharge areas.

at the Sheep Range (pl. 1, M2), the Groom Range (pl. 1, M3), Rainier Mesa (pl. 1, M4), Shoshone Mountain (pl. 1, M5), Stonewall Mountain (pl. 1, M6), Gold Mountain (pl. 1, M7), Palmetto Mountains (pl. 1, M8), Grapevine Mountains (pl. 1, M9), Black Mountains (pl. 1, M10), and the Kingston Range (pl. 1, M11).

Potentiometric-surface depressions are indicators of ground-water discharge areas. The largest depression and the terminal discharge area of the regional ground-water flow system occur at Death Valley (pl. 1, D1). The depression, controlled dominantly by topography, forms the terminus of the regional ground-water flow system. Lesser depressions in the region occur at Mesquite Lake (pl. 1, D2), Stonewall Flat (pl. 1, D3), and Sarcobatus Flat (pl. 1, D4) 


\section{Troughs}

Two prominent troughs are controlled by geologic structure. The trough north of the Spring Mountains (pl. 1, T1) is a prominent feature that has been described by several investigators as the result of high-permeability, faulted, and fractured rock present along the axis of the Spotted Range-Mine Mountain structural zone (fig. 7; Winograd and Thordarson, 1975; Carr, 1984; Waddell and others, 1984; and Faunt, 1994). The trough located at Pahute Mesa (pl. 1, T2) is the result of a linear feature believed to be a fault (fig. 7; Blankennagel and Weir, 1973). Less prominent troughs that also may be structurally controlled occur at Amargosa Valley (pl. 1, T3) (Carr, 1984), Grapevine Canyon (pl. 1, T4) (Malmberg and Eakin, 1962; Carr, 1984) and Stonewall Pass (pl. 1, T5) (Rush, 1968). Troughs that may be controlled by topography and lithology are located at Yucca Flat (pl. 1, T6) and Emigrant Valley (pl. 1, T7) (Winograd and Thordarson, 1975). A trough that may be associated with all three controls is located at Fortymile Wash (pl. 1, T8) (Waddell, 1982).

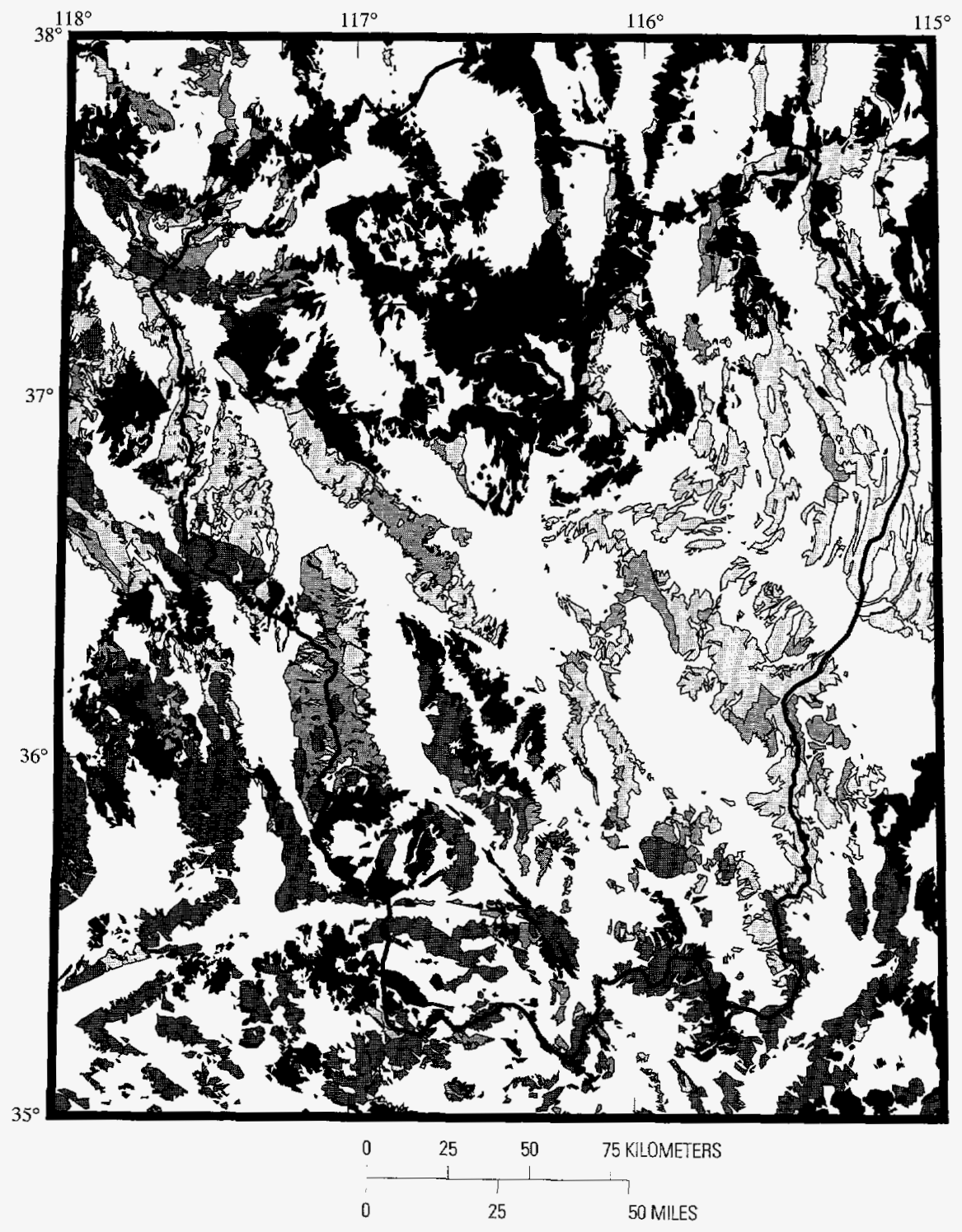

EXPLANATION

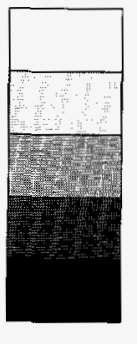

Basin fill deposits

Carbonate rocks

Clastic rocks

Crystalline rocks

Volcanic rocks

Death Valley regional groundwater flow system boundary

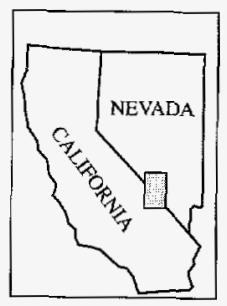

Figure 7. Locations of selected major structural features.

12 An Estimated Potentiometric Surface of the Death Valley Region, Nevada and California, Developed Using Geographic Information System and Automated Interpolation Techniques 


\section{Large Hydraulic Gradients}

Large hydraulic gradients, here defined as gradients larger than 0.1 , may be controlled by recharge, lithology, topography, structure, or by a combination of any of these factors. A large hydraulic gradient area at the northern part of Yucca Mountain (p1. 1, G1) has been discussed by several investigators (Czarnecki and Waddell, 1984; Waddell and others, 1984; Sinton, 1987; Ervin and others, 1994; Fridrich and others, 1994; Tucci and Burkhardt, 1995). However, large hydraulic gradients are a common feature of the Death Valley regional ground-water flow system.

Three regional-scale domains of large hydraulic gradient (pl. 1) exist in the study area (Waddell and others, 1984; Fridrich and others, 1994). One domain separates Death Valley from adjoining areas to the northeast and east (pl. 1, G2). This abrupt drop in water-table altitude is associated with contacts between low-permeability rocks in the Amargosa Range and higher permeability rocks in Death Valley, associated with the Death Valley fault zone (fig. 7). The large hydraulic gradient also may be a result of the large topographic change between the Amargosa Valley (land-surface altitude about 700 meters) and Death Valley (land-surface altitude about -80 meters).

The second domain occurs along the northern and western margins of the Spring Mountains (pl. 1, G3). The large hydraulic gradient in this area is associated with low-permeability, clastic confining units present north and west of the Spring Mountains. North of the Spring Mountains, the large hydraulic gradient also appears to be related to the Las Vegas Valley shear zone (fig. 7), and may be due to lowpermeability fault gouge developed in this major fault zone (Winograd and Thordarson, 1975).

The third domain extends from Yucca Mountain (pl. 1, G1) northeastward to Emigrant Valley (pl. 1, G4). This regional domain is the result of three largescale features (Fridrich and others, 1994): (1) a largely buried contact of regional confining units and the carbonate aquifer; (2) a generally southward topographic decline that approximately coincides with the regional potentiometric-surface declines; and (3) large regional recharge areas present to the north and west, in the vicinity of Pahute Mesa.

\section{SUMMARY}

Numerous potentiometric-surface maps have been developed for basins within the Death Valley region; however, most have been contour maps of shallow, unconfined basin-fill aquifers. Contour maps of shallow and deep, regional flow in consolidated rock have been developed, but none exist for the entire Death Valley regional ground-water flow system.

Regional water-level data were gathered from the USGS NWIS data base and incorporated with supplemental related data. These multiple data were interpolated by an initial convergent gridding algorithm and, subsequently, interactively edited to produce a regional potentiometric-surface map constrained to reflect regional topographic, geologic, and hydrologic system conditions. The resulting map is a description of predicted regional water levels that match all measured water levels and agree with previous estimates of the location of the potentiometric surface in areas lacking water-level measurements.

The potentiometric surface of the Death Valley ground-water basin contains several characteristics that may reflect important hydrologic features. These features include (1) potentiometric-surface mounds, (2) potentiometric-surface depressions, (3) potentiometric-surface troughs, and (4) large hydraulic gradients. These features are important descriptors of ground-water response to recharge and discharge conditions, as well as topographic and geologic controls.

\section{REFERENCES CITED}

Bedinger, M.S., Harrill, J.R., Langer, W.H., Thomas, J.M., and Mulvihill, D.A., 1984, Maps showing groundwater levels, springs, and depth to ground water, Basin and Range province, Nevada: U.S. Geological Survey Water-Resources Investigations Report 83-4119-B, scale 1:500,000.

Bedinger, M.S., Sargent, K.A., Langer, W.H., eds., 1989, Studies of geology and hydrology in the Basin and Range Province, southwestern United States, for isolation of high-level radioactive waste--Characterization of the Death Valley region, Nevada and California: U.S. Geological Survey Professional Paper 1370-F, 49 p.

Blankennagel, R.K., and Weir, J.E., Jr., 1973, Geohydrology of the eastern part of Pahute Mesa, 
Nevada Test

Site, Nevada: U.S. Geological Survey Professional Paper 712-B, $35 \mathrm{p}$.

Carr, W.J., 1984, Regional structural setting of Yucca Mountain, southwestern Nevada, and late Cenozoic rates of tectonic activity in part of the southwestern Great Basin, Nevada and California: U.S. Geological Survey Open-File Report 84-854, 114 p.

Czarnecki, J.B., and Waddell, R.K., 1984, Finite-element simulation of ground-water flow in the vicinity of Yucca Mountain, Nevada-California: U.S. Geological Survey Water-Resources Investigations Report $84-4349,38 \mathrm{p}$.

D'Agnese, F.A., 1994, Using geoscientific information systems for three-dimensional modeling of regional ground-water flow systems, Death Valley region, Nevada and California: unpublished PhD dissertation, Dept. of Geology and Geological Engineering, Colorado School of Mines, Golden, Colorado, $331 \mathrm{p}$.

Domenico, P.A., and Schwartz, F.W., 1990, Physical and Chemical Hydrogeology: John Wiley and Sons, New York, 824 p.

Ervin, E.M., Luckey, R.R., and Burkhardt, D.J., 1994, Revised potentiometric-surface map, Yucca Mountain and vicinity, Nevada: U.S. Geological Survey WaterResources Investigations Report 93-4000, 30 p.

Faunt, C.C., 1994, Characterization of the threedimensional hydrogeologic framework of the Death Valley region, Nevada and California: unpublished PhD dissertation, Dept. of Geology and Geological Engineering, Colorado School of Mines, Golden, Colorado, $256 \mathrm{p}$.

Faunt, C.C., D'Agnese, F.A., and Turner, A.K., 1993, Development of Three-Dimensional Hydrogeologic Framework Model for the Death Valley region, Southern Nevada-California, USA: Hydro GIS'93; Application of Geographic Information Systems in Hydrology and Water Resources, Proceedings of the Vienna Conference, April 1993, LAHS Publication 211,1993, p. 227-224.

Faunt, C.C., D'Agnese, F.A., and Turner, A.K., 1997, A hydrogeologic map of the Death Valley region, Nevada and California developed using GIS techniques: U.S. Geological Survey Water-Resources Investigations Report 95-4016, 18 p., 1 pl.

Fenneman, N.M., 1931, Physiography of western United States: McGraw-Hill Book Company, Inc., New York, 534 p.

Fridrich, C.J., Dudley, Jr., W.W., Stuckless, J.S., 1994, Hydrogeologic analysis of the saturated-zone ground-water system, under Yucca Mountain, Nevada: Journal of Hydrology, v. 154, nos. 1-4, pp. 133-168.

Grose, T.L., and Smith, G.I., 1989, Geology, in Bedinger, M.S., Sargent, K.A., and Langer, W.H., eds. Studies of geology and hydrology in the Basin and Range Province, southwestern United States, for isolation of high-level radioactive waste: U.S. Geological Survey Professional Paper 1370-F, p. 5-19.

Kilroy, K.C., 1991, Ground-water conditions in Amargosa Desert, Nevada-California, 1952-87: U.S. Geological Survey Water-Resources Investigations Report 89-4101, 93 p.

Langer, W.H., Moyle, W.R., Woolfenden, L.R., and Mulvihill, D.A., 1984, Maps showing ground-water levels, springs, and depth to ground water, Basin and Range province, southern California: U.S. Geological Survey Water-Resources Investigations Report 83-4119-B, scale 1:500,000.

Malmberg, G.T., 1967, Hydrology of the valley-fill and carbonate-rock reservoirs, Pahrump Valley, NevadaCalifornia: U.S. Geological Survey Water-Supply Paper 1832, $47 \mathrm{p}$.

Malmberg, G.T., and Eakin, T.E., 1962, Ground-water appraisal of Sarcobatus Flat and Oasis Valley, Nye and Esmeralda Counties, Nevada: Nevada Dept. of Conservation and Natural Resources-Ground-water Resources-Reconnaissance Series Report 10, 39 p.

Meinzer, O.E., 1923, Outline of ground-water hydrology, with definitions: U.S. Geological Survey WaterSupply Paper 494, 71 p.

Mifflin, M.D., 1988, Region 5, Great Basin, in Back, W., Rosenshein, J.S., and Seaber, P.R., eds., Hydrogeology: Boulder, CO, Geological Society of America, The Geology of North America, v. 02, pp. 69-78.

Pistrang, M.A., and Kunkel, Fred, 1964, A brief geologic and hydrologic reconnaissance of the Furnace Creek Wash area, Death Valley National Monument, California: U.S. Geological Survey Water-Supply Paper $1779-\mathrm{Y}, 35 \mathrm{p}$.

Robison, J.H., 1984, Ground-water level data and preliminary potentiometric-surface maps, Yucca Mountain and vicinity, Nye County, Nevada: U.S. Geological Survey Water-Resources Investigations Report $84-4197,8$ p.

Rush, F.E., 1968, Water-resources appraisal of Clayton Valley-Stonewall Flat Area, Carson City, Nevada and California: Nevada Dept. of Conservation and Natural Resources, Water Resources-Reconnaissance Series Report 45, 53 p.

Rush, F.E., 1970, Regional ground-water systems in the Nevada Test Site Area, Nye, Lincoln, and Clark Counties, Nevada: U.S. Geological Survey Water Resources-Reconnaissance Series Report 54, 25 p.

14 An Estimated Potentiometric Surface of the Death Valley Region, Nevada and California, Developed Using Geographic Information System and Automated Interpolation Techniques 
Sinton, P.O., 1987, Three-dimensional, steady-state, finitedifference model of the ground-water flow system in the Death Valley ground-water basin, NevadaCalifornia: unpublished Master of Engineering thesis, Dept. of Geology and Geological Engineering, Colorado School of Mines, Golden, $145 \mathrm{p}$.

Thordarson, William, and Robinson, B.P., 1971, Wells and springs in California and Nevada within 100 miles of the point $37^{\circ} 15^{\prime} \times$ north, $116^{\circ} 25^{\prime}$ west, on the Nevada Test Site: U.S. Geological Survey Open-File Report 474-85, $178 \mathrm{p}$.

Tucci, Patrick, and Burkhardt, D.J., 1995, Potentiometricsurface map, 1993, Yucca Mountain and vicinity, Nevada: U.S. Geological Survey Water-Resources Investigations Report 95-4149, 15 p.

Turner, A.K., D'Agnese, F.A., and Faunt, C.F., 1996a, Digital hydrographic, land use-land cover, and hydrologic unit code files for the Death Valley region of southern Nevada and southeastern California processed from U.S. Geological Survey 1:100,000and 1:250,000-scale digital data files: U.S. Geological Survey Open-File Report 95-362, $21 \mathrm{p}$.

Turner, A. Keith, D'Agnese, F.A., and Faunt, C.C., 1996b, Digital Elevation Model (DEM) file of topographic elevations for the Death Valley region of southem Nevada and southeastern California processed from U.S. Geological Survey 1-Degree (3-arc-second)
Digital Elevation Model (DEM) data files, U.S. Geological Survey Open-File Report 95-287, 9 p.

U.S. Geological Survey, 1985, Digital line graphs from 1:100,000-scale maps: U.S. Geological Survey, National Mapping Program Technical Instructions Data Users Guide 2, $74 \mathrm{p}$.

U.S. Geological Survey, 1987, Digital elevation models: U.S. Geological Survey, National Mapping Program Technical Instructions Data Users Guide 5, $38 \mathrm{p}$.

Waddell, R.K., 1982, Two-dimensional, steady state model of ground-water flow, Nevada Test Site and vicinity, Nevada-California: U.S. Geological Survey WaterResources Investigations Report 82-4085, $77 \mathrm{p}$.

Waddell, R.K., Robison, J.H., and Blankennagel, R.K., 1984, Hydrology of Yucca Mountain and vicinity, Nevada-California-Investigative results through mid-1983: U.S. Geological Survey Water-Resources Investigations Report 84-4267, 72 p.

Walker, G.E., and Eakin, T.E., 1963, Geology and ground water of Amargosa Desert, Nevada: California: U.S. Geological Survey Ground-Water ResourcesReconnaissance Series Report 14, 45 p.

Winograd, I.J., and Thordarson, William, 1975, Hydrologic and hydrochemical framework, south-central Great Basin, Nevada-California, with special reference to the Nevada Test Site: U.S. Geological Survey Professional Paper 712C, p. CI-C126. 


\section{NOTICE}

Page(s) size did not permit electronic reproduction. Information may be purchased by the general public from the National Technical Information Service, U.S. Department of Commerce, Springfield, VA 22161 (Area Code 703-487-4650). DOE and DOE contractors may purchase information by contacting DOE's Office of Scientific and Technical Information, P.O. Box 62, Oak Ridge, TN 37831, Attn: Information Services (Area Code 423-576-8401). 